Journal of Applied Pharmaceutical Science Vol. 5 (08), pp. 139-142, August, 2015

Available online at http://www.japsonline.com

DOI: $10.7324 / \mathrm{JAPS} .2015 .50821$

ISSN 2231-3354 (cc)) BY-NC-SA

\title{
Immuno stimulant activity of Heterostemma tanjorense (Wight \& Arn) on azathioprine induced male albino rats
}

\author{
S. Manikandaselvi ${ }^{1 *}$, A. R. Angumeenal ${ }^{1}$, S. Thilagam ${ }^{1}$, V. Poornima ${ }^{1}$, R. Thinagarbabu ${ }^{2}$ \\ ${ }^{1}$ School of Chemical \& Biotechnology, SASTRA University, Thanjavur, Tamilnadu, India. \\ ${ }^{2}$ Department of Biochemistry, S.T.E.T Women's college, Mannargudi, Tamilnadu, India.
}

\begin{tabular}{l}
\hline ARTICLE INFO \\
\hline Article history: \\
Received on: $25 / 03 / 2015$ \\
Revised on: $09 / 05 / 2015$ \\
Accepted on: $19 / 06 / 2015$ \\
Available online: $28 / 08 / 2015$ \\
\hline
\end{tabular}

Key words:

Immunostimulant,

Heterostemma tanjorense,

Immunoglobulins, Immune

system, Azathioprine.

\begin{abstract}
Immunostimulators are substances that stimulate the immune system by increasing the activity of any of its individual component biological systems. The selected plant species Heterostemma tanjorense Wight \&Arn is an area specific medicinal plant. Literature review made on this species reveals not much of its medicinal activity to be explored and documented. The present study reports the immune stimulant activity of Heterostemma tanjorense on azathioprine administered male albino rats. Biological parameters such as RBC, WBC, neutrophils, neutrophil adhesive and immunoglobulins were evaluated and the results were reported.The results obtained were in significant quantities and in reportable amounts.
\end{abstract}

\section{INTRODUCTION}

Reduced Immune system activity is responsible for various diseases such as arthritis, ulcerative colitis, asthma, allergy, parasitic and infectious diseases, while defective immune mechanisms are the main cause for diseases such as diabetes mellitus, cancer, myocardial diseases, cirrhosis and atherosclerosis (Samter et al., 1971). These difficulties can be overcome by boosting the immune system using selective immune-stimulant drugs (Ragap, 2012). Azathioprine is an immuno suppressant drug used during organ transplantation and in autoimmune diseases such as rheumatoid arthritis and pemphigus or inflammatory bowel disease such as Crohn syndrome and ulcerative colitis (Gillett and Chan, 2000). It is a prodrug, which in the body is converted to the active metabolite 6-mercaptopurine and 6-thioiosinic acid. Azathioprine act by inhibiting the purine synthesis necessary for the proliferation of cells, especially leucocytes and lymphocytes (Konstantopoulou, 2005).

* Corresponding Author

Manikandaselvi Sambasivam, Department of Biochemistry, S.T.E.T

Women's college, Mannargudi, Tamilnadu, India.

Email: selvithinagar@gmail.com
Immunostimulators are substances that stimulate the immune system by increasing the activity of any of its component systems. An example for such a stimulator include granulocyte macrophage colony stimulating factor (Soehnlein, 2008). Immuno stimulators belong to any one of the following two categories (Antony et al., 2005), viz. 1-Specific immuno stimulators-vaccine or any antigen 2-Non-specific immuno stimulators-adjuvant female sex hormones (Azuma and Jolles, 1987).

More attention is now being given to certain new synthetic immuno stimulators and to their clinical applications in cancer and infectious diseases. The use of plants for medicinal purposes has a very long and unbroken history in the Indian subcontinent (Sumalatha et al., 2012). Natural products, especially the plants used in "Indian traditional medicine" are the potential source of such immunostimulatory compounds. The present study aims at evaluating the aqueous extract of Heterostemma tanjorense Wight \&Arn for immuno stimulant activity with a view of developing leads for new therapeutic products. The main biochemical constituents of Heterostemma tanjorense Wight \& Arncomprise flavonoids, triterpenoids, tannins, steroids and anthroquinone. They are used in ophthalmopathy, orchitis, cough, burning sensation, stomachalgia, consumption, fever and tridosa (Thevasundari and Rajendran, 2012). 


\section{MATERIALS AND METHODS}

Male albino rats weighing between 150-200 g were used for this study. Animal handling and experimental procedures followed were all approved by the Institutional Animal Ethical committee. The animals were kept under a 12-h light/dark cycles at $22^{\circ} \mathrm{C}$ and $60 \%$ humidity along with food and water ad libitum.

\section{Collection of plant}

The medicinally viable parts of Heterostemma tanjorense Wight \&Arn was collected from Herbal Garden, STET Women's College,Mannargudi, which were carefully examined and identified with the help of regional Floras (Nair and Henry, 1987). Specimens were further confirmed with reference to Herbarium sheets available in the Botanical survey of India, (CSIR), Coimbatore, Tamilnadu.

\section{Extraction of plant material}

Medicinally useful aerial parts were collected from the field and dried in shade for a period of ten days. The collected parts of this plant were processed, dried in shade and powdered by pulverizes.

\section{Experimental protocol}

The male albino rats chosen for the study were divided in to six groups and each group was experimented as follows,

Group I: Rats of this group were treated as control and were administrated with $0.9 \%$ normal saline once in a day for a total period of 21 days.

Group II: Rats of this group were administrated with 10 $\mathrm{mg}$ dose of azathioprine per day from the first day up to the 21 st day.

Group III: Rats of this group were administrated with $10 \mathrm{mg}$ of azathioprine once in a day, from the $1^{\text {st }}$ to the $7^{\text {th }}$ day and were administered with an aqueous extract of 50 mg plant powder of Heterostemma tanjorens eWight \&Arn from the $8^{\text {th }}$ to the $21^{\text {st }}$ day at an interval of 24 hours.

Group IV: Rats of this group were administrated with 10 $\mathrm{mg}$ of azathioprine once in a day, from the $1^{\text {st }}$ to the $7^{\text {th }}$ day and were administered with an aqueous extract of $100 \mathrm{mg}$ plant powder of Heterostemma tanjorense Wight \&Arn from the $8^{\text {th }}$ to the $21^{\text {st }}$ day at an interval of 24 hours.

Group V: Rats were administrated with a $10 \mathrm{mg}$ dose of dry powder of azathioprine from the $1^{\text {st }}$ to the $7^{\text {th }}$ day, and an aqueous extract of $150 \mathrm{mg} / \mathrm{kg}$ from 8 thto the $21^{\text {st }}$ day at an interval of 24 hours.
Group VI: Rats were administrated with $10 \mathrm{mg}$ dose per day of azathioprine from the $1^{\text {st }}$ to the $7^{\text {th }}$ day and were administered with $200 \mathrm{mg}$ plant powder of Heterostemma tanjorense Wight \& Arn in water from the $8^{\text {th }}$ to $21^{\text {st }}$ day at an interval of 24 hours.

At the end of the experimental period of 3 weeks (i.e., on 22nd day), all rats from each group were sacrificed by cervical decapitation and various biochemical parameters were analyzed. Fresh blood was immediately collected by cardiac puncture in fresh sterilized tubes, allowed to clot and the serum was separated by centrifugation at $2500 \mathrm{rpm}$ for 15 minutes. The sterile, hemolysis-free serum samples were subjected to biochemical investigation. Hematological parameters, namely the red blood cells (RBC) count and white blood cells (WBC) count was measured by standard procedures (D'Amour et al., 1965). Estimation of Neutrophils adhesive was done by Leishman's staining method (Kajaria, 2013). Proteins were estimated by Lowry's method (Lowry et al., 1951). To detect the immunoglobulins IgG, IgM, IgA, agarose gel electrophoresis was performed (Araki, 1958).

\section{Results}

Herbal preparations are becoming increasingly popular for a variety of diseases and infections, primarily influencing the host defense mechanism (Yadav, 2011). Immuno stimulating agents of plant and animal origin enhance the immune responsiveness of an organism against a pathogen by activating the immune system (Patil et al., 1998). Generally animals act as good models for numerous experiments in the field of pharmacology (Löscher, 2011).The selected medicinal plant, Heterostemma tanjorense Wight \& Arn. Has been identified to possess immuno stimulant activity against Azathioprine administered rats. The results of the study made are revealed.

\section{Haematological parameters RBC (Table-1)}

Among the experimental group of albino rats, those rats that were administered with azathioprine were found to show lower RBC than all the remaining groups $(1.05 \pm 0.11$ million $/ \mu \mathrm{l})$. But in the herbal drug administered group of rats the RBC profile shows a gradual change upon change in the concentrations of plant extract supplied $(5.22 \pm 0.56 \mathrm{~d}, 5.48 \pm 0.34$ million $/ \mu \mathrm{l})$. The RBC count in the group of rats were the dosage was maximum $(200 \mathrm{mg})$ was close to that measured in the control group of rats(3.51 \pm 0.49 million $/ \mu \mathrm{l})$.

\section{WBC (Table-1)}

Results of the WBC count reveal that their content was less in rats when administered with azathioprine (3.28 \pm 0.34 thousands $/ \mu \mathrm{l})$. WBC profile was profoundly elevated when the selected plant powder and extract were given to the test groups. (group III\& group IV) and at still more high concentrations of drug WBC raised close to normal.(4.51 \pm 0.76 thousands $/ \mu \mathrm{l})$. 
Table 1: Hematological profile of albino rats on administeringHetrostemmatanjorense Wight \&Arn.

\begin{tabular}{lcccccc}
\hline S.No. & Animals & $\begin{array}{c}\text { RBC } \\
\text { (Million/cubic mm.) }\end{array}$ & $\begin{array}{c}\text { WBC } \\
\text { (Thousand/ cubic mm. })\end{array}$ & $\begin{array}{c}\text { Protein } \\
(\mathbf{m g} / \mathbf{d l})\end{array}$ & $\begin{array}{c}\text { Neutrophils } \\
(\text { Thousand/ cubic mm. })\end{array}$ & $\begin{array}{c}\text { Neutrophil adhesive } \\
(\%)\end{array}$ \\
\hline 1. & Group -1 & $3.29 \pm 0.32$ & $5.27 \pm 0.67$ & $5.43 \pm 0.36$ & $23.57 \pm 0.27$ & $33.56 \pm 0.23$ \\
2. & Group II & $1.05 \pm 0.11^{\mathrm{d}}$ & $3.28 \pm 0.34^{\mathrm{a}}$ & $3.02 \pm 0.61^{\mathrm{d}}$ & $12.40 \pm 0.51^{\mathrm{a}}$ & $21.31 \pm 0.21$ \\
3. & Group III & $5.22 \pm 0.56^{\mathrm{d}}$ & $8.67 \pm 0.37^{\mathrm{a}}$ & $5.29 \pm 0.94^{\mathrm{d}}$ & $15.13 \pm 0.67^{\mathrm{a}}$ & $22.35 \pm 0.16$ \\
4. & Group IV & $5.48 \pm 0.34^{\mathrm{d}}$ & $8.40 \pm 0.40^{\mathrm{a}}$ & $4.95 \pm 0.88^{\mathrm{d}}$ & $15.39 \pm 0.56^{\mathrm{a}}$ & $25.41 \pm 0.25$ \\
5. & Group V & $2.42 \pm 0.20$ & $5.97 \pm 0.69$ & $5.39 \pm 0.96$ & $23.40 \pm 0.23$ & $27.37 \pm 0.22$ \\
6. & Group VI & $3.51 \pm 0.49$ & $4.51 \pm 0.76$ & $5.53 \pm 0.84$ & $22.14 \pm 0.20$ & $30.18 \pm 0.21$ \\
\hline
\end{tabular}

\section{Protein (Table- 1)}

The results of the protein analysis in the test animals reveal that the protein production is decreased in rats with azathioprine administration and there was also less production in cases with low drug concentrations, but the protein profile shows an increase when the drug levels goes high $(5.53 \pm 0.84 \mathrm{mg} / \mathrm{dl})$.

\section{Neutrophil (Table-1)}

Neutrophil content of experimental groups has exhibited varied responses. Comparing with the normal rats, those animals fed with azathioprine had less neutrophil production i.e., almost reduced to one half, but this started increasing when the selected medicinal plant drug was given at high doses.

Group of rats from II to VI neutrophil amount was observed to risegradually almost close to normal level especially at a dose of $200 \mathrm{mg}$ herbal drug (22.14 \pm 0.20 thousands $/ \mu \mathrm{l})$.

\section{Neutrophil adhesive (Table-1)}

Among all the groups, those groups of rats that were administered with high drug concentrations gave high neutrophil adhesive $(30.18 \pm 0.21 \%)$. In rats that were administered with azathioprine and in rats given with $50 \mathrm{mg}$ dosage of drug there was a raise in neutrophil adhesive content.

\section{Immunoglobulin (Table 2)}

Immunoglobulin $\mathrm{G}$ levels reduced in the experimental rats due to the administration of Azathioprine. Normal rat were measured to produce $860 \mathrm{mg} / \mathrm{dl}$ to $515 \mathrm{mg} / \mathrm{dl}$. Ig G levels kept decreasing on increasing the drug quantity and become equal at $200 \mathrm{mg}$ concentration.

Table 2: Immunoglobulin ( $\operatorname{IgM}, \operatorname{Ig} A$ and $\operatorname{IgG}$ ) levels in test rats with Hetrostemmatanjorense Wight \&Arn

\begin{tabular}{ccccc}
\hline S.No. & Animals & $\begin{array}{c}\text { Ig G } \\
(\mathbf{m g} / \mathbf{d l})\end{array}$ & $\begin{array}{c}\text { Ig A } \\
(\mathbf{m g} / \mathbf{d l})\end{array}$ & $\begin{array}{c}\text { IgM } \\
(\mathbf{m g} / \mathbf{d l})\end{array}$ \\
\hline $\mathbf{1}$ & Group -1 & 860 & 172 & 7.8 \\
2 & Group II & 515 & 102 & 3.4 \\
3 & Group III & 582 & 129 & 4.4 \\
4 & Group IV & 632 & 137 & 5.1 \\
5 & Group V & 790 & 160 & 6.8 \\
6 & Group VI & 840 & 173 & 7.7 \\
\hline
\end{tabular}

The same trend in drug action was observed in $\mathrm{Ig} \mathrm{M}$ levelsls also. It is to note that the quantity of immunoglobulins decreased when azathioprine was administered. A regular trend in drug action could be identified when the drug concentration was gradually raised with respect to IgA levels.

\section{DISCUSSION}

Immunostimulant agents of plant and animal origin enhance the immune responsiveness of an organism against a pathogen by activating the immune system (Sathianarayanan, 2012). However these agents and the herbal formulations should be subjected to systematic studies to substantiate the therapeutic claims made with respect to their clinical utility (Kulkarni and Karande, 1998).

In this study, the hematological parameters exhibited results that supported the immunostimulant activity ofthe medicinal plant Heterostemma tanjorense Wight \&Arn..Earlier also hematological parameters are the supporting evidences for the immunostimulant activity in neem bark (Vander Nat et al., 1987). Recently, an aqueous extract of stem bark has been shown to enhance the immune response of Balb-c mice to sheep red blood cells in vivo (Njiro et al., 1999). The aqueous extract of leaf also possesses potent immunostimulant activity as evidenced by both humoral and cell-mediated responses (Sen et al., 1992). Neem oil has been shown to possess immunostimulant activity by selectively activating the cell-mediated immune mechanisms to elicit an enhanced response to subsequent mitogenic or antigenic challenge (Upadhyay et al., 1992).

Immunosuppressive conditions were induced by the administration of Azathioprine. Highly elevated or reduced conditions of biochemical compounds gave significant results due to the administrations of Heterostemma tanjorense Wight \& Arn (at doses of 50, 100, $150200 \mathrm{mg} / \mathrm{kg}$ ). Higher concentrations of selected drug activity were very effective, which was nearby the normal values of RBC and WBC. Neutrophil adhesive factorsand neutrophil index also have remarkable changes in the experimental groups. Highly decreased amount of protein level was increased by the administration of higher dose of plant extract.

In this study, suppressed amount of immunoglobulins were recorded from the administration of Azathioprine, which was gradually increased due to the administration of this plant product. Normal albino rat containing $\mathrm{IgG}$ range from $86 \mathrm{mg} / \mathrm{dl}$ to $515 \mathrm{mg} / \mathrm{dl}$. The percentage was higher in groups administered with higher doses. $150 \mathrm{mg} / \mathrm{rat}$ administered has higher amount of immunoglobulin A (148mg/dl) and IgM was 5.6mg/dl in group IV. Same levels of immunoglobulin status were recorded in the study of leaf extract at $100 \mathrm{mg} / \mathrm{kg}$ after three weeks of oral 
administration. There are reports stating that administration causes higher IgM and IgG levels along with increased titre of antiovalbumin antibody (Ray et al., 1996).

Heterostemma tanjorense Wight \& Arn has shown significant immunostimulant effect in animals. Therefore clinical and phytochemical screening especially secondary metabolic compounds can lead to discovery of new drug.

\section{REFERENCES}

Antony PA et al. CD8+ T cell immunity against a tumor/selfantigen is augmented by CD4 $+\mathrm{T}$ helper cells and hindered by naturally occurring T regulatory cells. J Immunol, 2005; 174(5): 2591-2601.

Araki. Immunoglobulin studies through the blotting techniques. Molecular Biology, 1958; 54: 132-135.

Azuma andJolles G., (eds.),. 1987. Immuno stimulants, p: 297.

D'Amou FE, Belden DA. 1965. Jr. Manual for Laboratory Work in Mammalian Physiology. $3^{\text {rd }}$ Edition. Chicago, Tex, USA: The University of Chicago Press.

Kajaria D, Tripathi JS, Tiwari SK, Pandey BL. Immunomodulatory effect of ethanolic extract of Shirishadi compound. Pharmacological Study, 2013; 34(3):322-326.

Gillett NA, Chan C. Applications of immunohistochemistry in the evaluation of immunosuppressive agents.Human \& Experimental Toxicology, 2000;19 (4) : 251-254.

Haney M. Ragap, Rheyad H. Khalil Hawazin H. Mutawie. Immunostimulant effects of dietary Spirulinaplatensis on tilapia Oreochromisniloticus. Journal of Applied Pharmaceutical Science, 2012; 02 (02): 26-31.

Konstantopoulou.Azathioprine-induced pancytopenia in a patient with pompholyx and deficiency of erythrocyte thiopurinemethyltransferase. BMJ, 2005; 330(7487): 350-351.

Kulkami SR, Karande VS. Study of immunostimulant activity of Napthoquinone extract of leaves of Lawsoniaalba. Indian Drugs, 1998; 35:427-433.

Lowry OH, Rosebrough, Nira J, Farr A Lewis, Randall, Rose J. Protein measurement with the Folin phenol reagent. J Biol Chem, 1951;193:265-75.

Njiro SM, Kafi-Tsekpo M W. Ondersterpoort. J. Vet. Res, $1999 ; 66: 59-62$.
Ray A, Banerjee BD, Sen P. Modulation of humoral and cell mediated responses. Ind J Exp Biol, 1996;34:678-701.

Samter M, 1971. Immunological diseases, $2^{\text {nd }}$ Edition, Little Brown and Company, Boston.

Sathianarayanan S, Rajasekaran A. Immuno modulatory activity of ethanolic extract of Wrightia tinctoria leaves. Int J Pharm Pharm Sci, 2012; 4(4): 251-254.

Sen P, Medinata PK. Immunostimulant activities of A. indica. Indian J. Exp. Biol., 1992; 12: 1170-1175.

Soehnlein O, Kenne E, Rotzius P, Eriksson EE, Lindbom L. Neutrophil secretion products regulate anti-bacterial activity in monocytes and macrophages. ClinExpImmunol, 2008;151:139-45.

Sumalatha, Rama Bhat P., Shwetha R. Ballal and Sadananda Acharya. Studies on immunomodulatory effects of salacia chinensis 1. On albino rats. J App Pharm Sci, 2012; 2(9): 98-107.

Thevasundari S, Rajendran A. Antifungal activity of Heterostemma tanjorense (Wight and Arn.). Asian Journal of Plant Science and Research, 2012; 2(3):330-334.

Upadhyay SN, Dhawan S, Garg S, Talwar GP. Immunomodulatory effects of neem (Azadirachta indica) oil. Int J.Immunopharmacol, 1992; 14:1187-1193.

Van der Nat JM, Klerx JP, Van Dijk H, De Silva KT, Labadie RP. Immunomodulatory activity of aqueous extract of Azadirachta indica stem bark. J Ethanopharmacol, 1987; 19:125-31.

Wolfgang Löscher . Critical review of current animal models of seizures and epilepsy used in the discovery and development of new antiepileptic drugs. Seizure 2011; 20(5):359-368.

Yadav Rajesh, Kharya Dhar Murli, Yadav Nita, Savadi Rudraprabhu. Immunomodulatory potential of ethanol extract of Spilanthus acmella leaves. Int J Biol Med Res, 2011; 2(3): 631-635.

\section{How to cite this article:}

Manikandaselvi S, Thilagam S, Angumeenal AR, Poornima V and Thinagarbabu R. Immuno stimulant activity of Heterostemma tanjorense (Wight \& Arn) on azathioprine induced male albino rats. J App Pharm Sci, 2015; 5 (08): 139-142. 